\title{
The Impact of Silver Nanoparticles on Bacterial Aerobic Nitrate Reduction Process
}

\author{
Samaneh Shahrokh ${ }^{1}$, Baharak Hosseinkhani ${ }^{2}$ and Giti Emtiazi ${ }^{1 *}$ \\ ${ }^{1}$ Department of biology, The University of Isfahan, Isfahan, I. R. Iran \\ ${ }^{2}$ Laboratory of Microbial Ecology and Technology (LabMET), Ghent University, Coupure, Links 653, B-9000 Gent, Belgium
}

\begin{abstract}
Due to the effective antimicrobial properties of silver nanoparticles (Ag NPs), these particles are receiving an extensive interest for applying in wide range of consumer products and water purification systems. Entering the Ag-based material in wastewater system can influence the biological cycle such as nitrogen. Denitrification as a part of nitrogen cycle is an effective biological process in wastewater systems which can be affected by Ag NPs. The objective of this research was to study the impact of Ag NPs on aerobic nitrate reduction. We showed that Rhizobium $s p$ and Azotobacter sp isolates were able to reduce nitrate aerobically. Adding $0.2 \mathrm{ppm}$ of Ag NPs in culture medium of Azotobacter $\mathrm{PHB}^{+}$enhanced the of the nitrate reduction activity about $20 \%$ and Ag NPs at this concentration has no significant effect on the nitrate reduction activity of periplasmic extracts of the selected isolates in aerobic conditions. Thus, entering certain ation of $\mathrm{Ag}$ NPs in environments has no significant impact on microbial aerobic denitrification as an important part of nitrogen cycle.
\end{abstract}

Keywords: Silver nanoparticles; Denitrification; Nitrate reduction; Bacteria

\section{Introduction}

Since the 1970, contamination of groundwater by nitrate (NO3-) has become a great concern for human health and harmful effect on environmental ecosystems due to carcinogenic influence and high rate of accumulation in surface water [1]. According to The European Union and World Health Organization (WHO), drinking contaminated water with more than $11.3 \mathrm{mg} \mathrm{L}^{-1}$ nitrogen are considering as unsafe water source especially for infants [2]. Hence, remediation of groundwater system contaminated with nitrate has been extensively studied over last decades. Biological processes including microbial denitrification has been considered as promising alternative for remediation of nitrate methods [1]. Aerobic nitrate respiration as a part of denetrification process has been detected in numbers of facultative anaerobic heterotrophic bacteria such as Pseudomonas sp., [3] Paracoccus pantotrophusm, [4] Pseudomonas aeruginosa, Rhodobacter sphaeroides f. sp. denitrificans [3]. Typically, Nitrate reductase as one of key enzyme in aerobic nitrate respiration is located in periplasmic [4].

Recent studies show that metal ions concentration is a critical parameter that affects the ability of denitrifying bacteria to remove nitrate and nitrite $[5,6]$. Over the past few decades, silver nanoparticles (Ag NPs) have been applied in wide range of commercial product such as catalysts, electronics, printing industry, photographic manufacturing, clothing, food industry, paints, cosmetics products and medical consumptions [7]. However, these wide ranges of applications of Agbased products caused an increasing in the risk of Ag-ions entering to the wastewater treatment systems [8]. Few reports are available concerning the interaction of Ag-based material and ions with environmental bacterial communities [9]. Therefore, it is essential to consider whether the entering silver compound and ions in the wastewater system can impact the activity of biological processes or not. This research aims to study the impact of Ag NPs on the aerobic reduction of nitrate, first step of the denitrification processes, in Azotobacter and Rhizobium isolates. To our knowledge, the effect of Ag-based material on denitrification has not been investigated yet. In this study the aerobic reduction of nitrate by Rhizobium sp. and Azotobacter sp. isolates was studied. Afterwards, the effect of Ag NPs on the nitrate reduction process catalyzed by native cells, cell free and periplasmic extracts of selected strains was evaluated.
In addition to, the bactericidal activity of Ag NPs on studied aerobic denitrifies was also examined.

\section{Materials and Methods}

\section{Bacteria, preparation of media and silver nanoparticles}

Rhizobium A1, Rhizobium A3, Azotobacter $\mathrm{PHB}^{+}$(previously isolated from meliloti nodules and soil of Isfahan respectively) and Escherichia coli ATCC 1339 (Gram negative model bacterium with ability of anaerobic nitrate reduction) were obtained from the microbial culture collection of microbiological laboratory of the University of Isfahan. All isolates were grown in the medium containing the following ingredients g per liter: $0.5 \mathrm{KH}_{2} \mathrm{PO}_{4}, 0.5 \mathrm{~K}_{2} \mathrm{HPO}_{4}, 0.2 \mathrm{MgSO}_{4} .7 \mathrm{H}_{2} \mathrm{O}, 3.0$ $\mathrm{CaCO}_{3} .2 \mathrm{H}_{2} \mathrm{O}, 0.001 \mathrm{MgSO}_{4} .5 \mathrm{H}_{2} \mathrm{O}, 1$ yeast extract, $0.1 \mathrm{NaCl}$ and 10 glucose and consequently the $\mathrm{pH}$ of the medium was adjusted to 7.5 [10].

Ag NPs (average size: $40 \pm 10 \mathrm{~nm}$ ) was obtained from Nanocid Company, Iran.

\section{MIC and MBC assay of Ag NPs}

To evaluation the minimum inhibitory concentration of Ag NPs on our strains, a serial dilution of Ag NPs $(0.25,0.5,1,2,4,8 \mathrm{ppm})$ was prepared. $80 \mu \mathrm{l}$ of sterile nutrient broth was added to 96 -well microtitre plates followed by adding $40 \mu \mathrm{l}$ of different concentration of Ag NPs to each row of the microtitre plates. $80 \mu \mathrm{l}$ of the bacterial suspension (adjusted to 0.5Mac Farland level) was then added to each row (resulting the final volume of $200 \mu \mathrm{l}$ cell suspension for each well). The microplate was sealed with plastic film and incubated at suitable temperatures

*Corresponding author: *Giti Emtiazi, Department of biology, The University of Isfahan, Isfahan, Iran; Tel: 98-311-7932457; E-mail: emtiazi@yahoo.com

Received February 06, 2014; Accepted February 22, 2014; Published March 02, 2014

Citation: Shahrokh S, Hosseinkhani B, Emtiazi G (2014) The Impact of Silver Nanoparticles on Bacterial Aerobic Nitrate Reduction Process. J Bioprocess Biotech 4: 152 doi: 10.4172/2155-9821.1000152

Copyright: (c) 2014 Shahrokh S, et al. This is an open-access article distributed under the terms of the Creative Commons Attribution License, which permits unrestricted use, distribution, and reproduction in any medium, provided the original author and source are credited. 
Citation: Shahrokh S, Hosseinkhani B, Emtiazi G (2014) The Impact of Silver Nanoparticles on Bacterial Aerobic Nitrate Reduction Process. J Bioprocess Biotech 4: 152 doi: 10.4172/2155-9821.1000152

$\left(28^{\circ} \mathrm{C}\right.$ and $\left.37^{\circ} \mathrm{C}\right)$ for $24 \mathrm{~h}$ according to each strain. Minimal bactericidal concentrations $(\mathrm{MBC})$ were determined by agar plate method $[11,12]$. All experiments were performed in triplicate.

\section{Growth in presence of $\mathrm{Ag} \mathrm{NPs}$}

Bacterial cell were exposed to Ag NPs by inoculating desired concentration of each strains $\left(1.5 \times 10^{8} \mathrm{CFU} / \mathrm{ml}\right)$ of all strains in to medium contained $25 \mathrm{ml}$ nutrient broth supplemented by $0.01 \% \mathrm{KNO}_{3}$ and $0.2 \mathrm{ppm}$ Ag NPs. All of flasks were incubated at $28^{\circ} \mathrm{C}$ for $24 \mathrm{~h}$ with mild shaking $(130 \mathrm{rpm})$. Nitrite reduction was assayed as described below. Growth of bacteria were monitored by measuring optical density of cells at $600 \mathrm{~nm}\left(\mathrm{OD}_{600}\right)$ over times.

\section{Nitrite assay}

The bacteria were grown in nutrient broth supplemented with $0.01 \% \mathrm{KNO}_{3}$ at $28^{\circ} \mathrm{C}$ with mild shaking $(130 \mathrm{rpm})$. Cells were harvested by centrifugation $(4,830 \mathrm{~g}$ for $10 \mathrm{~min})$ in sterile $50 \mathrm{~mL}$ centrifuge tubes. One $\mathrm{ml}$ of supernatant was transferred to $3 \mathrm{ml}$ cuvettes. Consequently, $0.02 \mathrm{ml}$ of nitrite determination reagent was added, mixtures were kept at room temperature for $15 \mathrm{~min}$. The pink color was measured spectrophotometrically at $540 \mathrm{~nm}$ against the blank [13]

\section{Nitrate reduction activity of native cells}

The nitrate reduction activity of aerobically grown bacterial cells was measured in the presence of nitrate $\left(100 \mathrm{mg} / \mathrm{L} \mathrm{NO}_{3}-\mathrm{N}\right)$. The cells were harvested by centrifugation $(10,000 \mathrm{~g}, 10 \mathrm{~min})$ at the middle of their exponential growth $\left(\mathrm{OD}_{660}\right.$ about 0.8$)$, washed 3 times and resuspended in $0.1 \mathrm{M}$ phosphate buffer, and $\mathrm{pH}$ 7.2. The concentration of cell suspensions was adjusted to $1.0\left(\mathrm{OD}_{600}\right)$ with $0.1 \mathrm{M}$ potassium phosphate buffer.

Five $\mathrm{ml}$ of each cell suspension was transferred into reaction tubes and nitrate solution was added in final concentration of $30 \mathrm{mg} \mathrm{L}^{-1}$ $\mathrm{NO}_{3}-\mathrm{N}$. Afterward, the following conditions were conducted for each isolates: (1) $0.5 \mathrm{~g} \mathrm{~L}^{-1}$ sodium thioglycolate and $0.2 \mathrm{ppm} \mathrm{Ag} \mathrm{NPs} \mathrm{were}$ added to suspension, (2) sodium thioglycolate free samples, (3) Ag NPs free samples, and also sodium thioglycolate and Ag NPs free controls.

The tubes were kept at room temperature for $60 \mathrm{~min}$. Nitrite was assayed in supernatant (harvested from biomass by centrifugation at $4,830 \mathrm{~g}$ for $10 \mathrm{~min}$ ) as described before [2,6].

\section{Nitrate reduction activity in cell free extract}

Cytoplasmic enzyme were obtained by following procedure, fresh biomass of cells were harvested from nutrient broth media containing $0.01 \% \mathrm{KNO}_{3}$ by centrifugation $(2,683 \mathrm{~g}$ and $30 \mathrm{~min})$. Pellets were resuspended in $0.1 \mathrm{M}$ phosphate buffer, pH 7.2. Consequently, cells were disrupted using an ultrasonic processor $(\mathrm{GmbH} \mathrm{VP} 200 \mathrm{H})$ in $(50 \mathrm{~Hz}$, 7 times, 30s) in an ice-water bath). After bacterial cell disruption, supernatant were separated by centrifugation $(11,180 \mathrm{~g}, 15 \mathrm{~min})$. One $\mathrm{ml}$ of supernatant was exposed to nitrate solution with final concentration of $30 \mathrm{mg} / \mathrm{l} \mathrm{NO}_{3}-\mathrm{N}$. Suspension was treated for nitrite assay as mentioned in pervious part. The tubes kept at room temperature for 60 min. Nitrite was then assayed according to Emtiazi et al. [14].

\section{Preparation of periplasmic extract and nitrate reduction activity}

Bacterial cells were harvested using centrifugation at $4,920 \mathrm{~g}$ for $10 \mathrm{~min}$. The supernatant were carefully removed from cells pellet. Pellets were re-suspended in ice-cold extraction buffer $(20 \mathrm{ml}$ of $1 \mathrm{X}$ TES buffer). Extraction buffer were contained: $0.2 \mathrm{M}$ Tris- $\mathrm{HCl}, 0.5 \mathrm{mM}$
EDTA, 0. $5 \mathrm{M}$ sucrose $\mathrm{pH}=8.00$. Thirty three $\mathrm{ml}$ of $1 / 5 \mathrm{X}$ TES was mixed with obtained biomass from each liter of cell culture. The resuspended cells were kept on ice for $30 \mathrm{~min}$. The obtained supernatant was carefully transferred (containing periplasmic extract) to tube and stored at -20 to $-70^{\circ} \mathrm{C}$ for further analysis as mentioned above [15]. The activity of nitrate reductase was assayed as described above.

\section{Results and Discussion}

\section{Screening of nitrate reductase positive-isolates}

Denitrification is typically occurring under anaerobic or anoxic conditions [6,16-18]. In addition, microbially aerobic nitrate reduction has also been reported by soil bacteria such as Pseudomonas, Arthrobacter, Moraxella and Aeromonas [19-21]. In this study, a comparative evolution in reduction of nitrate by different strains of Rhizobium and Azotobacter showed that Rhizobium A1, A3 and Azotobacter $\mathrm{PHB}^{+}$were the best strains in aerobically reducing nitrate (Table 1). Further studies were carried out using these strains.

\section{MIC and MBC determination of Ag NPs}

Cho et al. [11] discovered the MIC of Ag NPs for Staphylococcus aureus and E. coli were 5 and $10 \mathrm{ppm}$, respectively [11]. In other research by Kim [7], the antimicrobial activities of Ag ions and Ag NPs against a Gram-negative E. coli and a Gram-positive strain such as $S$. aureus were investigated and they found Ag NPs having greater bactericidal activity against $E$. coli compared with $S$. aureus. Petica et al. [22] showed that stable solutions containing up to $35 \mathrm{ppm}$ of Ag have significant antimicrobial and antifungal properties [22]. Choi et al. [8] showed that $0.5 \mathrm{mgL}^{-1} \mathrm{Ag}$ has the inhibitory effect on the growth of E. coli PHL628gfp in the forms of $\mathrm{Ag} \mathrm{NPs}, \mathrm{Ag}^{+}$ions, and $\mathrm{Ag} \mathrm{Cl}$ colloids by $5578 \%$, $100 \%$, and $6676 \%$, respectively [8]. In this study, the bactericidal activity of Ag NPs on E. coli and different soil isolates with ability of nitrate reduction, Rhizobium and Azotobacter, was determined. Exposing of these bacteria to different concentration of Ag NPs solution revealed that the growth of all strains was completely inhibited by $8 \mathrm{ppm}$ of $\mathrm{Ag}$ NPs. In general, results showed that the MIC of Ag NP for Rhizobium and Azotobacter was $1 \mathrm{ppm}$ and in case of E. coli was $2 \mathrm{ppm}$ (Table 2). Briefly, it was discovered that $0.2 \mathrm{ppm}$ of Ag NPs had no effect on growth of soil bacteria. Therefore, this concentration can be applied as an effective concentration of Ag NPs for further experiments regarding the the effect of these NPs on the responsible enzyme in reduction of nitrate as one of the key enzyme of nitrogen cycle.

\section{Effect of Ag NPs on bacterial growth and nitrate reduction}

\begin{tabular}{|l|c|c|c|c|c|}
\hline \multicolumn{1}{|c|}{ Isolates } & OD $_{543 \mathrm{~nm}}$ & Isolates & OD $_{543 n m}$ & Isolates & OD $_{543 \mathrm{~nm}}$ \\
\hline Rhizobium 4R & 0.001 & Rhizobium PS2 & 0.095 & Azotobacter P11 & 0.242 \\
\hline Rhizobium A3 & 0.219 & Rhizobium A1 & 0.250 & Azotobacter P81 & 0.001 \\
\hline Rhizobium 6R & 0.121 & Rhizobium Sin1 & 0.005 & Azotobacter A1 & 0.002 \\
\hline Rhizobium A4 & 0.108 & Rhizobium D1 & 0.002 & Azotobacter D1 & 0.255 \\
\hline Rhizobium $\mathrm{A}_{2} \mathrm{~A}$ & 0.072 & Rhizobium 1R & 0.036 & Azotobacter D2 & 0.000 \\
\hline Rhizobium $\mathrm{A}_{2} \mathrm{~B}$ & 0.192 & Rhizobium 2R & 0.216 & Azotobacter PHB & 0.282 \\
\hline
\end{tabular}

Table 1: Comparative evaluation of nitrate reduction by different strains of Rhizobium, Azotobacter.

\begin{tabular}{|c|c|c|}
\hline Bacteria & MIC & MBC \\
\hline Rhizobium $A 1$ & $1 \mathrm{ppm}$ & $8 \mathrm{ppm}$ \\
\hline Rhizobium $A 3$ & $1 \mathrm{ppm}$ & $8 \mathrm{ppm}$ \\
\hline Azotobacter PHB $^{+}$ & $1 \mathrm{ppm}$ & $8 \mathrm{ppm}$ \\
\hline E.coli & $2 \mathrm{ppm}$ & $8 \mathrm{ppm}$ \\
\hline
\end{tabular}

Table 2: MIC and MBC assay of Ag NPs on different strains of Rhizobium Azotobacter and E.coli. 
Citation: Shahrokh S, Hosseinkhani B, Emtiazi G (2014) The Impact of Silver Nanoparticles on Bacterial Aerobic Nitrate Reduction Process. J Bioprocess Biotech 4: 152 doi: 10.4172/2155-9821.1000152

Page 3 of 4
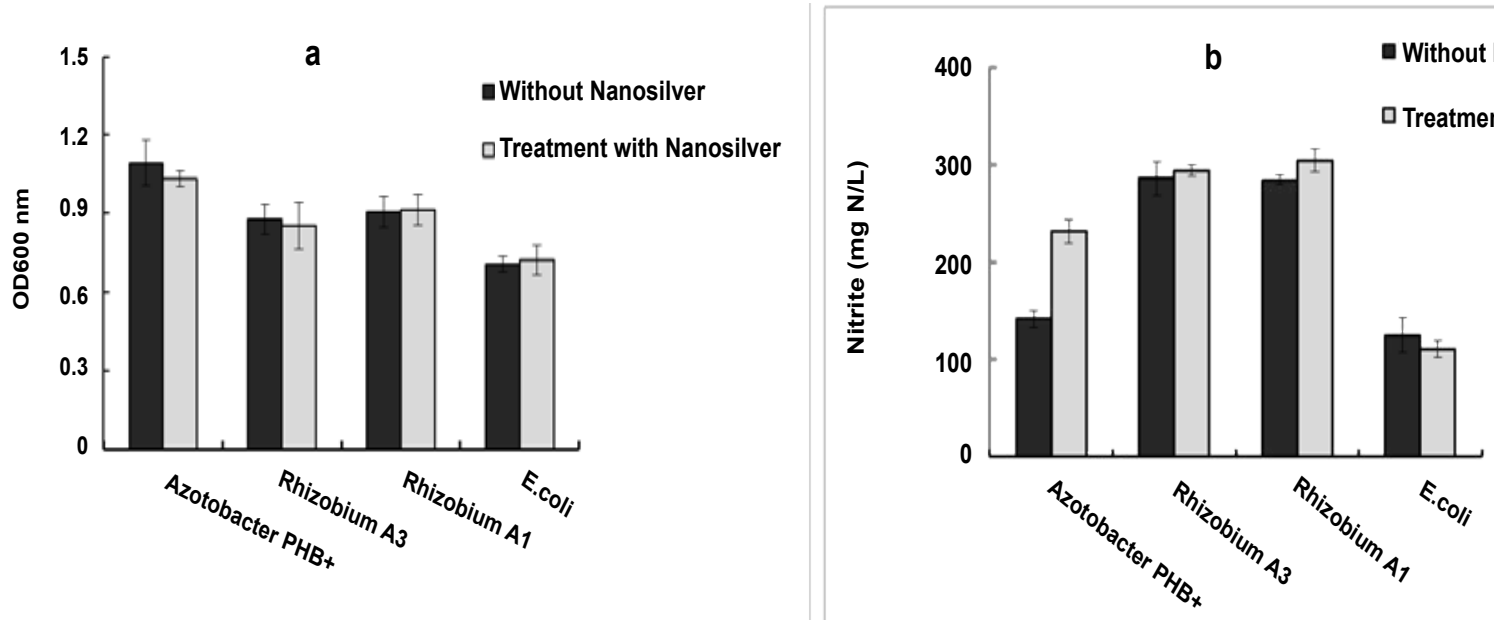

Figure 1: Comparative evaluation of effect of $0.2 \mathrm{ppm}$ of Ag NPs on growth of studied bacteria [2] and nitrate reduction rate (b).

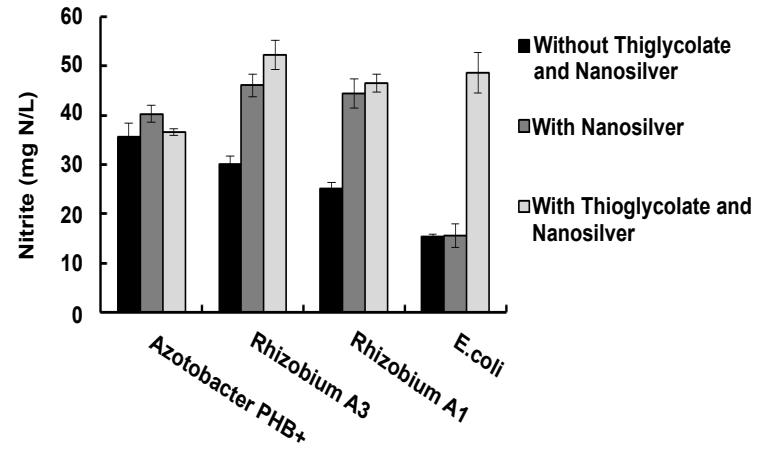

Figure 2: Comparative evaluation of nitrate reduction in native cells, cells treated by Ag NPs and sodium thioglycolate, cells treated by Ag NPs and cells without any treatments.

The effects of sodium thioglycolate as reducing agent and Ag NPs on the enzymatic activity of the strains were investigated. We discovered that using $0 \mathrm{Ag}$ NPs in the concentration of $0.2 \mathrm{ppm}$ had no significant effect on nitrate reductase activity of Rhizobium A1 and A3. Interestingly, an increasing up to $20 \%$ in the nitrate reduction activity of Azotobacter $\mathrm{PHB}^{+}$was observed in compare with untreated cell (Figure 1). An increase in the amount of nitrite in these samples may be explained by the catalytic properties of Ag-based particles in reduction of nitrate [23].

\section{Impact of Ag NPs on the nitrate reduction process in native cells}

Kariminiaae-Hamedaani et al. [2] and Pintathong et al. [6] were studied the nitrate reduction activity of native cells of Pseudomonas sp. ASM-2-3 and Paracoccus pantotrophus P16 [2,6]. In our study, aerobic reduction of nitrate in native cells of the strains was investigated. Figure 2 represents that the nitrate reductase of selected bacterial cell were still active after 60 minutes. In contrast with the E.coli, nitrate reduction activity in soil isolates was not significantly affected by sodium thioglycolate and even this activity was higher in the presence of $\mathrm{Ag}$ NPs in compared to the controls. A significant increase in the activity of nitrate reductase of E.coli in the presence of sodium thioglycolate suggested that it may provide a suitable reduced condition for more efficient activity of this enzyme. It can be confirmed that this strain was not able simply to reduce nitrate in aerobic condition.

Impact of Ag NPs with nitrate reduction activity in the cell free and periplasmic extract compartments

Nitrate reductase activity in the cell free and periplasmic extract was tested under aerobic conditions. Extracted enzyme from sonicated cells showed a significant decreasing in activity in compare with blanks. This can be related to the sensitivity of these enzymes to oxygen or disturbing the appropriate order of the enzyme subunits in the cytoplasmic membrane.

It has been found that periplasmic nitrate reductase play a main role in aerobic nitrate reduction. To define the membrane-bound and periplasmic nitrate reductase of bacteria such as Rhodobacter capsulatus, Rhodobacter sphaeroides $f$. sp. denitrificans, Alcaligenes eutrophus, Paracoccus denitrificans PD1222 and GB17, Pseudomonas putida and Escherichia coli the non-physiological electron donor $\left(\mathrm{BV}^{+}\right.$ and $\mathrm{MV}^{+}$) method have been applied [19, 24].

Periplasmic nitrate reductase has been characterized as a responsible enzyme for aerobic nitrate reduction $[2,23]$. To our knowledge, the effect of Ag NPs on the activity of aerobic nitrate reductase has not been investigated yet. Unlike the previous studies, this study for the first time demonstrates the activity of periplasmic nitrate reductase in the periplasmic extract of the cells. Interestingly, we observed that all soil isolates, excluding E.coli, have had significant high periplasmic nitrate reductase activity in the presence of oxygen while adding sodium thioglycolate had no significant effect on its activity (Figure 3). Therefore our result showed that the presence of thioglycolate and anaerobic condition is not necessary for activity of this enzyme.

Increasing in the concentration of Ag NPs up to 4 ppm caused a $40 \%$ decrease in enzyme activity of Rhizobium A1 (Figure 3 and 4 ).

\section{Conclusions}

In conclusion, Ag NPs can enhance the activity of nitrate reductase in native bacteria cells while have not such effect on cell free extracted enzyme. According to our finding, periplasmic nitrate reductase is responsible for aerobic nitrate reduction and specific concentrations 
Citation: Shahrokh S, Hosseinkhani B, Emtiazi G (2014) The Impact of Silver Nanoparticles on Bacterial Aerobic Nitrate Reduction Process. J Bioprocess Biotech 4: 152 doi: 10.4172/2155-9821.1000152

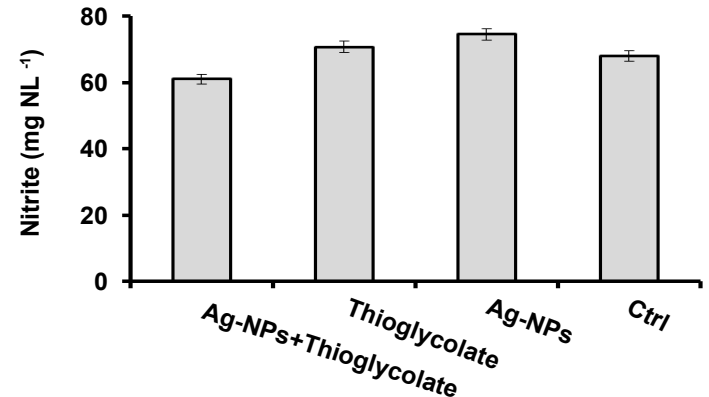

Figure 3: Investigation of nitrate reduction activity in the periplasmic extract of Rhizobium A1 in different conditions including: (1) addition of Ag NPs and sodium thioglycolate, (2) sodium thioglycolate free samples, (3) Ag NPs free samples and (4) controls without any treatment.

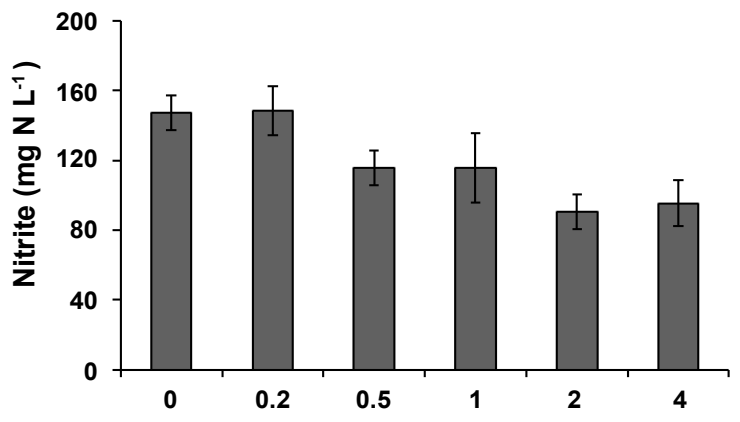

Figure 4: The periplasmic nitrate reductase activity of Rhizobium A1 in presence of different concentration of Ag NPs.

of Ag NPs have no significant effect on this activity. Therefore, the results of this study suggest that Ag NPs at certain concentration can be a promising biocide for applying in recirculating wastewater treatment systems. Moreover, this study introduced an efficient method for extracting periplasmic nitrate reductase enzyme. This enzyme can apply for further applications in wastewater treatment, applying in reduction of metals and formation of nanoparticles and etc.

\section{Acknowledgment}

Authors would like to thank to the University of Isfahan, Iran for financially supporting this research.

\section{References}

1. Rivett MO, Buss SR, Morgan P, Smith JWN, Bemment CD (2008) Nitrate attenuation in groundwater: A review of biogeochemical controlling processes. Water Res 42: 4215-4232.

2. Kariminiaae-Hamedaani H-R, Kanda K, Kato F (2004) Denitrification activity of the bacterium Pseudomonas sp. ASM-2-3 isolated from the Ariake Sea tideland. J Biosci Bioeng 97: 39-44.

3. Bedzyk L, Wang T,Ye RW (1999) The periplasmic nitrate reductase in Pseudomonas sp strain G-179 catalyzes the first step of denitrification. J Bacteriol 181: 2802-2806

4. Stewart V, Lu YR,Darwin AJ (2002) Periplasmic nitrate reductase (NapABC enzyme) supports anaerobic respiration by Escherichia coli K-12. J Bacteriol 184: $1314-1323$

5. Aiken AM, Peyton BM, Apel WA, Petersen JN (2003) Heavy metal-induced inhibition of Aspergillus niger nitrate reductase: applications for rapid contaminant detection in aqueous samples. Analytica Chimica Acta 480: 131-142.
6. Pintathong P, Richardson DJ, Spiro S, Choorit W (2009) Influence of metal ions and organic carbons on denitrification activity of the halotolerant bacterium, Paracoccus pantotrophus P16 a strain from shrimp pond. Electron J Biotechnol 12.

7. Abou El-Nour KMM, Eftaiha Aa, Al-Warthan A, Ammar RAA (2010) Synthesis and applications of silver nanoparticles. Arabian J Chem 3: 135-140.

8. Choi O, Deng KK, Kim N-J, Ross Jr L, Surampalli RY, et al. (2008) The inhibitory effects of silver nanoparticles, silver ions, and silver chloride colloids on microbial growth. Water Res 42: 3066-3074.

9. Das P, Xenopoulos MA, Williams CJ, Hoque ME, Metcalfe CD (2011) Effects of silver nanoparticles on bacterial activity in natural waters. Environ Toxicol Chem 31: 122-130.

10. Shakeri S, Roghanian R, Emtiazi G (2012) Surveillance of single-cell behavior in different subpopulations of Ralstonia pickettii AR1 during growth and polyhydroxybutyrate production phases by flow cytometry. J Basic Microb 52: 206-215.

11. Cho KH, Park JE, Osaka T, Park SG (2005) The study of antimicrobial activity and preservative effects of nanosilver ingredient. Electrochimica Acta 51: 956-960.

12. Dizman B, Elasri MO, Mathias LJ (2004) Synthesis and antimicrobial activities of new water-soluble bis-quaternary ammonium methacrylate polymers. J Appl Polym Sci 94: 635-642.

13. Zhu L, Ding W, Feng L-j, Kong Y, Xu J, et al. (2012) Isolation of aerobic denitrifiers and characterization for their potential application in the bioremediation of oligotrophic ecosystem. Bioresource Technol 108: 1-7.

14. Emtiazi G, Saleh T, Hassanshahian M (2009) The effect of bacterial glutathione S-transferase on morpholine degradation. Biotech J 4: 202-205.

15. Lo BC, Kontermann R, Ikel T, Korn T (2004) Production of Recombinan Bispecific Antibodies. Antibody Engineering, Methods in Molecular Biology 248 227-242.

16. Chang YJ,Tseng SK (1998) A new method for carbon addition in an anoxic denitrification bioreactor. Biotechnol Tech 12: 367-371.

17. Downey RJ (1966) Nitrate Reductase and Respiratory Adaptation in Bacillus Stearothermophilus. J Bacteriol 91: 634-641.

18. Furina EK, Nikolaeva DA, Bonartseva GA, Myshkina VL, L'Vov NP (2002) Reduction of nitrates by Azotobacter indicum and Azotobacter chroococcum cultures. Appl Biochem Micro 38: 558-561.

19. Carter JP, Hsiao YS, Spiro S, Richardson DJ (1995) Soil and Sediment Bacteria Capable of Aerobic Nitrate Respiration. Appl Environ Micro 61: 2852-2858.

20. Chen F, Xia Q, Ju LK (2003) Aerobic Denitrification of Pseudomonas aeruginosa Monitored by Online NAD(P)H Fluorescence. Appl Environ Micro 69: $6715-6722$.

21. Korner H, Zumft WG (1989) Expression of denitrification enzymes in response to the dissolved-oxygen level and respiratory substrate in continuous culture of pseudomonas-stutzeri. Appl Environ Micro 55: 1670-1676.

22. Petica A, Gavriliu S, Lungu M, Buruntea N, Panzaru C (2008) Colloidal silver solutions with antimicrobial properties. Mat Sci Eng B 152: 22-27.

23. Shen J, Shan W, Zhang YH, Du JM, Xu HL, et al. (2004) A novel catalyst with high activity for polyhydric alcohol oxidation: nanosilver/zeolite film. Chem Commun 24: 2880-2881.

24. Bell LC, Richardson DJ, Ferguson SJ (1990) Periplasmic and membrane-bound respiratory nitrate reductases in Thiosphaera pantotropha: The periplasmic enzyme catalyzes the first step in aerobic denitrification. FEBS Letters 265 85-87. 